The Free Internet Journal

for Organic Chemistry
Review

Arkivoc 2020, part i, 1-19

\title{
Synthesis and activities of tricyclic pyrido[3,4-g]quinazolines, pyrazolo[3,4- g]quinoxalines and pyrroloindazole regioisomers
}

\author{
Fabrice Anizon*and Pascale Moreau* \\ Université Clermont Auvergne, CNRS, SIGMA Clermont, ICCF, F-63000 Clermont-Ferrand, France \\ Emails: fabrice.anizon@uca.fr, pascale.moreau@uca.fr
}

Received 11-13-2020

Accepted 01-09-2020

Published on line 03-14-2020

\section{Abstract}

Heteroaromatics constitute an important class of organic compounds with wide-ranging applications. This account, including patent literature, describes reported synthetic methods leading to tricyclic nitrogencontaining heterocyclic systems (pyrido[3,4-g]quinazolines, pyrazolo[3,4-g]quinoxalines and pyrroloindazoles) which are found in many biologically active compounds.

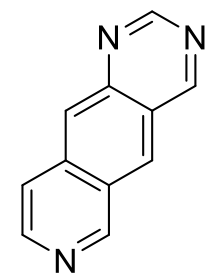

Pyrido[3,4-g]quinazolines<smiles>c1cnc2cc3[nH]ncc3cc2n1</smiles>

Pyrazolo[3,4-g]quinoxalines

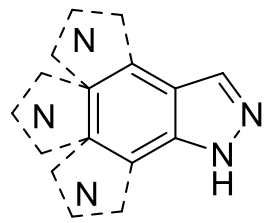

Pyrroloindazole regioisomers

Keywords: Nitrogen-containing heterocyclic systems, pyrido[3,4-g]quinazolines, pyrazolo[3,4-g]quinoxalines; pyrroloindazoles 


\section{Table of Contents}

1. Introduction

2. Synthesis and Biological Activities of Pyrido[3,4-g]quinazolines

3. Synthesis and Biological Activities of Pyrazolo[3,4-g]quinoxalines

4. Synthesis and Biological Activities of Pyrroloindazole Regioisomers

4.1. Pyrrolo[2,3-e]indazoles

4.2. Pyrrolo[3,2-e]indazoles

4.3. Pyrrolo[3,2-f]indazoles

4.4. Pyrrolo[2,3-g]indazoles

4.5. Pyrrolo[3,4-g]indazoles

4.6. Pyrrolo[3,2-g]indazoles

5. Conclusions

References

\section{Introduction}

Heteroaromatics containing systems such as indole, indazole or pyrazole constitute a large family of organic compounds with a wide range of applications in biology ${ }^{1-4}$ as active ingredients or molecular probes due to their biological and physicochemical properties. Some heteroaromatic derivatives are also of high interest due to their application in organic optoelectronic materials. ${ }^{5}$ Therefore, the development of new synthetic methodologies allowing access to these classes of compounds has given rise to numerous studies. ${ }^{6}$ As part of our work aiming at identifying new biologically active skeletons, we are particularly interested in the design and synthesis of novel structural series with protein kinase inhibitory potencies.

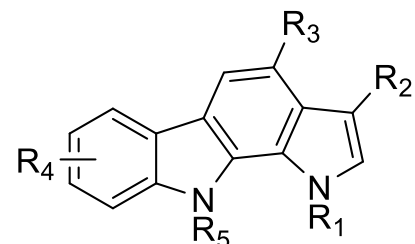

1,10-dihydropyrrolo[2,3-a]carbazoles<smiles>[R]c1nc2cc3cn[nH]c3cc2nc1[R]</smiles>

Pyrazolo[3,4-g]quinoxalines<smiles></smiles>

K252c analogues

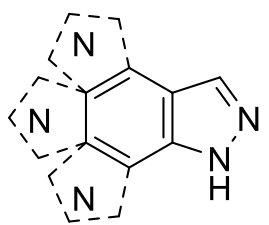

Pyrroloindazole regioisomers<smiles>[R]c1ccc2cnc3c([R])cc4[nH]ncc4c3c2c1</smiles>

Pyrazolo[4,3-a]phenanthridines<smiles>Nc1ncc2cc3cnccc3cc2n1</smiles>

Pyrido[3,4-g]quinazolines

Figure 1. Nitrogen-containing heteroaromatic scaffolds found in protein kinase inhibitors developed by our group. 
The scaffolds presented Figure 1 are found in potent protein kinase inhibitors (targeting Pim kinases, except for the pyrido[3,4-g]quinazoline series which exhibited activities toward DYRK1A/CLK1). Synthesis and properties of various series such as dihydropyrrolocarbazoles ${ }^{4}$ and indolocarbazoles ${ }^{7}$ have already been reviewed while very few examples of pyrazolo[4,3-a]phenanthridines can be found in the literature. Therefore, due to our interest in these tricyclic systems we decided to focus this account on pyrido[3,4g]quinazolines, pyrazolo[3,4-g]quinoxalines and pyrroloindazole regioisomers (Figure 2). To the best of our knowledge, none of these fully aromatic systems has been reported so far, the majority of syntheses concerning dihydropyrroloindazole derivatives. Moreover, the synthesis of some series was never or rarely reported, such as pyrrolo[3,4-e]-, pyrrolo[2,3-f]- and pyrrolo[3,4-f]indazoles.<smiles>c1cc2cc3cncnc3cc2cn1</smiles><smiles>c1cnc2cc3[nH]ncc3cc2n1</smiles>

Pyrido[3,4-g]quinazolines Pyrazolo[3,4-g]quinoxalines<smiles></smiles>

Pyrrolo[2,3-e]indazole<smiles>c1cc2[nH]ncc2cn1</smiles>

Pyrrolo[3,4-e]indazole<smiles></smiles>

Pyrrolo[3,2-e]indazole<smiles></smiles>

Pyrrolo[2,3-f]indazole<smiles></smiles>

Pyrrolo[3,4-f]indazole<smiles>C1=Cc2cc3c(cc2=N1)N=NC=3</smiles>

Pyrrolo[3,2-f]indazole<smiles>C1=Cc2c3c(ccc2=N1)=CN=N3</smiles>

Pyrrolo[2,3-g]indazole<smiles></smiles>

Pyrrolo[3,4-g]indazole<smiles>C1=Nc2c3c(ccc2=C1)=CN=N3</smiles>

Pyrrolo[3,2-g]indazole

Figure 2. Structure of pyrido[3,4-g]quinazolines, pyrazolo[3,4-g]quinoxalines and regioisomeric series of pyrroloindazoles.

\section{Synthesis and biological activities of pyrido[3,4-g]quinazolines}

The pyrido[3,4-g]quinazoline scaffold was designed in our group on the basis of a structure-activity relationship study performed around meridianins, marine alkaloids isolated from the ascidian Aplidium meridianum, possessing an indole moiety substituted in the 3-position by a 2-aminopyrimidine ring. The best activities were found for CLK1 and DYRK1A kinases where nanomolar potencies were encountered. After molecular modelling studies, the design of a second generation of inhibitors ended up with this new pyridoquinazoline series (Scheme 1$)^{8}$ 


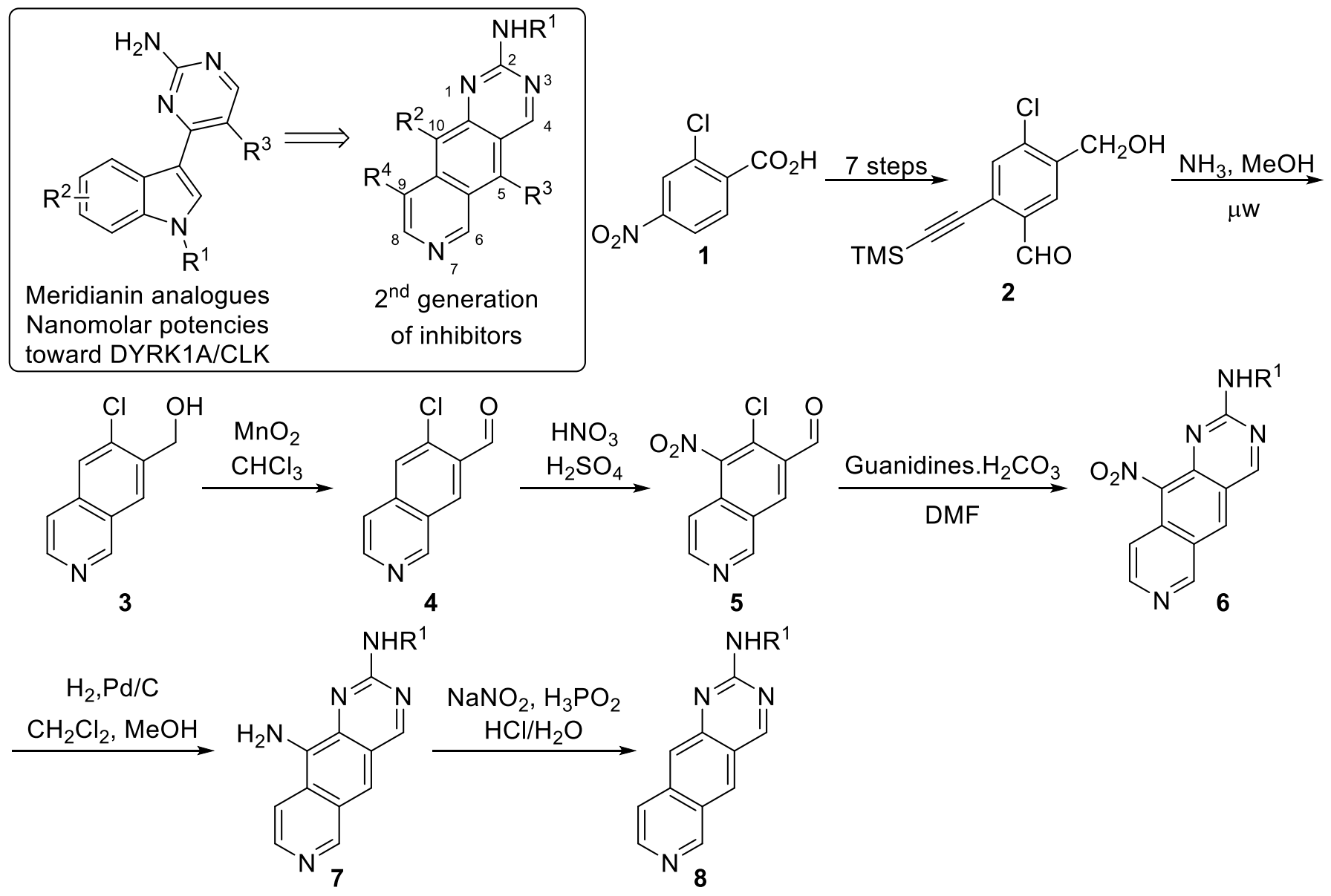

Scheme 1. Design and synthesis of pyrido[3,4-g]quinazolines. ${ }^{8-10}$

The synthesis of this pyridoquinazoline scaffold was achieved via intermediate 2, a tetrasubstituted benzene derivative obtained in seven steps from benzoic acid derivative 1 using trivial aromatic chemistry (Scheme 1). The upper substituents are necessary to establish the aminopyrimidine moiety and the lowers to form the pyridine part. The isoquinoline ring system was first formed under microwave irradiation in the presence of ammonia in methanol. Next, oxidation of 3 using $\mathrm{MnO}_{2}$ led to the isoquinoline 4 . Then, the regioselective introduction of a nitro group at the ortho position to the chlorine atom was necessary to ensure a suitable reactivity of the system, with respect to amidine or guanidinium salts, in order to obtain the tricyclic system $\mathbf{6}$. Catalytic hydrogenation of 6 led to the corresponding amino derivatives. The amino group could be removed from $7\left(R^{1}=H\right)$ after diazotation/reduction. ${ }^{8-10}$ The reaction of compound $6\left(R^{1}=H\right)$ with organolithium or Grignard reagents allowed the introduction of alkyl/aryl substituents at the 5-position $\left(R^{3}\right)$ while electrophilic aromatic substitution led to the functionalization of the 9-position $\left(R^{4}=\mathrm{Br}\right) .{ }^{11} \mathrm{All}$ compounds were evaluated towards CDK5/p25, CK1 $\delta / \varepsilon, \mathrm{GSK}-3 \alpha / \beta$, DYRK1A and CLK1. Nanomolar activities were observed toward DYRK1A/CLK1. Nitro derivatives were generally more active towards CLK1 in comparison to DYRK1A whereas amino analogues could exert potent activities towards both CLK1 and DYRK1A or, in some cases were more active towards DYRK1A. Therefore, this series affords interesting research tools to study DYRK1A/CLK1 protein kinases.

An example of a related compound (14, Scheme 2$)$ is reported in a patent dealing with the identification of factor IXa inhibitors. ${ }^{12}$ In this case, the formation of the pyridoquinazoline derivative scaffold (compound 13) 
was achieved by cyclization under basic conditions of the corresponding 6-acylamino-7carboxamidoquinazoline 12 prepared in 3 steps from 6-amino-7-cyano-2H-isoquinoline-1-one 9.
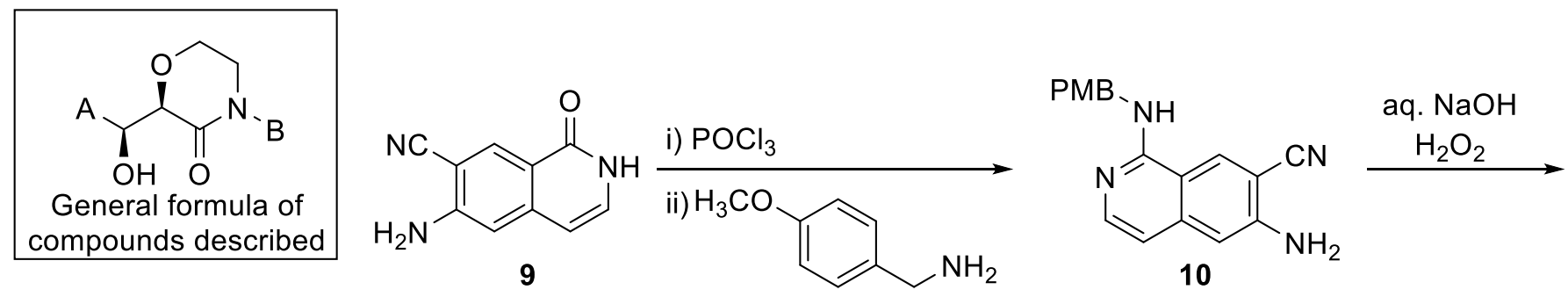<smiles>CC(C)(C)Nc1nccc2cc(NC(=O)[C@@H](O)[C@H]3OCCN(c4ccn(-c5ccncc5)n4)C3=O)c(C(N)=O)cc12</smiles>

PMB<smiles>CC(C)(C)C(C)(C)C(C)(C)C(C)(C)C</smiles>

Scheme 2. Structure and synthesis of factor IXa inhibitors containing a pyridoquinazoline moiety. ${ }^{12}$

\section{Synthesis and biological activities of pyrazolo[3,4-g]quinoxalines}

Pyrazolo[3,4-g]quinoxaline is another scaffold that has attracted great interest for its biological potential. Compounds 16 or its methylated analogue 17 were prepared at $-50{ }^{\circ} \mathrm{C}$ or $0{ }^{\circ} \mathrm{C}$, respectively, in moderate yields by dipolar cycloaddition reactions using quinoxalinequinone 15 and diazomethane (Scheme 3 ). ${ }^{13} \mathbf{1 7}$ was also prepared from the corresponding methoxy analogue 19 using ceric ammonium nitrate (Scheme 3). ${ }^{14}$

As part of our work aiming at the identification of Pim kinase inhibitors, we prepared diversely substituted tetra- and tricyclic analogues. ${ }^{15,16}$ These compounds (e.g. 21) were obtained in moderate yields by reacting $1 \mathrm{H}$-indazole-5,6-diamine 20 and suitable 1,2-dicarbonyl compounds (Scheme 3). ${ }^{16}$ 
<smiles>CCOC(=O)N(CC)OCCOCCN</smiles><smiles>[R]n1ncc2c1C(=O)c1cc(-c3ccc(C)cc3)c(-c3ccc(C)cc3)cc1C2=O</smiles><smiles>Cc1ccc(-c2cc3c(O)ccc(O)c3cc2-c2ccc(C)cc2)cc1</smiles>

or $17\left(\mathrm{R}=\mathrm{CH}_{3}\right)$

Yields

\begin{tabular}{c|c|c} 
Temperature & 16 or 17 & 18 \\
\hline$-50{ }^{\circ} \mathrm{C}$ & $16,45 \%$ & $45 \%$ \\
$0{ }^{\circ} \mathrm{C}$ & $17,42 \%$ & $41 \%$
\end{tabular}<smiles></smiles>

19

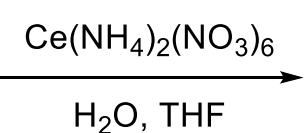

$\mathrm{H}_{2} \mathrm{O}, \mathrm{THF}$<smiles>Cc1ccc(-c2cc3c(cc2-c2ccc(C)cc2)C(=O)c2c(cnn2C)C3=O)cc1</smiles>

$17,80 \%$<smiles></smiles>

22, $\mathrm{R}=\mathrm{R}^{\prime}=\mathrm{Ph}$

23, $\mathrm{R}=\mathrm{CH}_{3}, \mathrm{R}^{\prime}=\mathrm{Ph}$ and $\mathrm{R}=\mathrm{Ph}, \mathrm{R}^{\prime}=\mathrm{CH}_{3}$

24, $\mathrm{R}$

$\mathrm{R}^{\prime}=\mathrm{Ph}$<smiles>[R]C(=O)C([R])=O</smiles>

20

Scheme 3. Synthesis of tricyclic pyrazolo[3,4-g]quinoxalines $\mathbf{1 6 , 1 7},{ }^{13,14} \mathbf{2 1}^{16}$ and $\mathbf{2 2 - 2 4} .^{17,18}$

High yielding access to diversely substituted analogues (22-24) was described by Linsdley's group using microwave irradiation. Compound $\mathbf{2 4}$ was reported as a submicromolar allosteric inhibitor of Akt (protein kinase B/PKB) (Scheme 3). ${ }^{17,18}$ Related compounds (general formula, Figure 3), similarly prepared from 20 and diversely substituted 1,2-dicarbonyls were also pointed out by the same group in patents presenting the use of Akt inhibitors in cancer therapy alone or in combination with inhibitor(s) of other protein kinase(s). ${ }^{19-21}$<smiles>[R]C1=Nc2cc3cn[nH]c3cc2N=C([R])C1[R]</smiles>

Figure 3. Examples of Alk inhibitors reported in patents. ${ }^{19-21}$ 
Other pyrazolo[3,4-g]quinoxalines were also synthesized similarly by reacting 5,6-diaminoindazole 20 and glyoxyloyl(Het)Ar 25. Pairs of separable regioisomers were obtained in all steps (compounds 26-31, Scheme 4). Evaluation of their PDGFR-inhibitory potency demonstrated nanomolar activities for the most active compounds. $^{22}$<smiles></smiles>

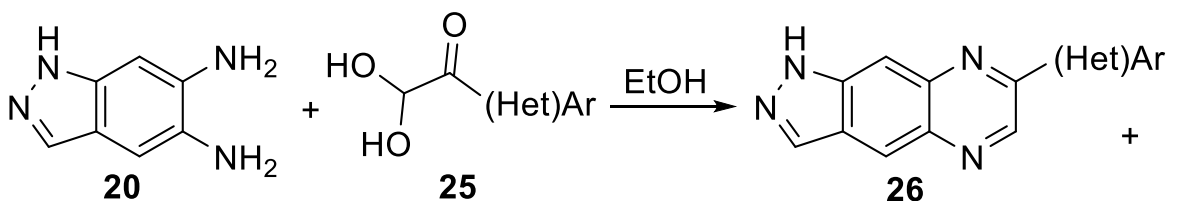<smiles>[Te][Mg]Cc1cnc2cc3[nH]ncc3cc2n1</smiles>

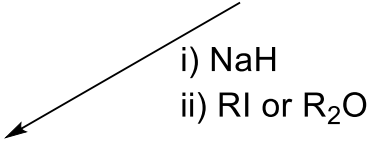

27

i) $\mathrm{NaH}$

i) $\mathrm{NaH}$

ii) $\mathrm{RI}$ or $\mathrm{R}_{2} \mathrm{O}$<smiles></smiles>

28<smiles>[R]n1cc2cc3nc(I)cnc3cc2n1</smiles>

30

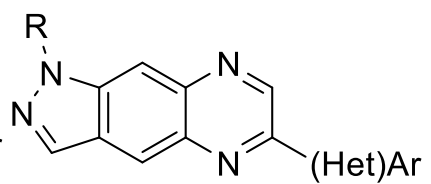

31

Scheme 4. General formula and synthesis of pyrazolo[3,4-g]quinoxalines with potential PDGFR-inhibitory potency 26-31. ${ }^{22}$

\section{Synthesis and biological activities of pyrroloindazole regioisomers}

\subsection{Pyrrolo[2,3-e]indazoles}

In 2000, V. M. Lyubchanskaya et al. reported the synthesis of 1,4-dihydropyrrolo[2,3-e]indazoles via a Nenitzescu indole synthesis from quinone derivatives 32 and enamines 33 (Scheme 5). ${ }^{23}$ Cyclization to the corresponding furo[2,3-e]indazoles was also observed, but was reduced when enamino esters $\left(33, R^{2}=O E t\right)$ substituted at the nitrogen atom with a methyl or a benzyl group $\left(\mathrm{R}^{1}=\mathrm{CH}_{3}\right.$ or $\mathrm{Bn}$ ) were used.<smiles>O=C1C=CC(=O)c2c1nn(-c1ccccc1)c2-c1ccccc1</smiles>

32

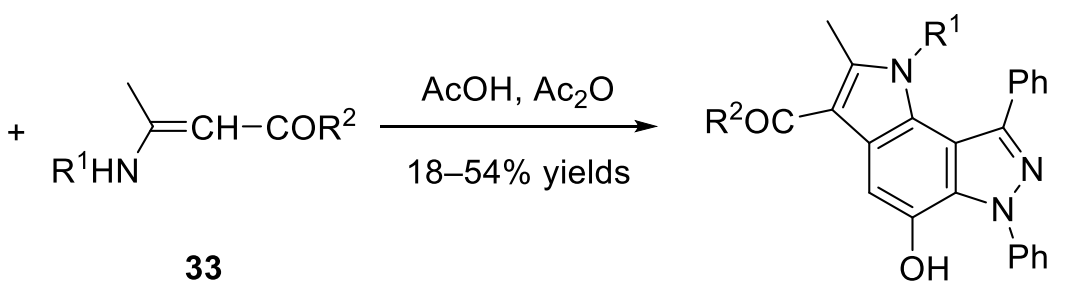

34

$$
\begin{aligned}
& \mathrm{R}^{1}=\mathrm{H}, \mathrm{CH}_{3}, \mathrm{Bn}, p-\mathrm{CH}_{3} \mathrm{O}-\mathrm{C}_{6} \mathrm{H}_{4} \\
& \mathrm{R}^{2}=\mathrm{OEt}, \mathrm{CH}_{3}, \mathrm{Ph}
\end{aligned}
$$

Scheme 5. Nenitzescu indole synthesis applied to the preparation of compounds $34 .^{23}$ 
Pyrrole ring formation from indazole derivatives was also the strategy adopted by Nerviano Medical Sciences to obtain the pyrrolo[2,3-e]indazole scaffold. ${ }^{24}$ In their PCT patent application, three different processes were reported, starting from 4-oxo-4,5,6,7-tetrahydroindazoles (Scheme 6). For example, from<smiles>CCOC(=O)c1[nH]c2c(c1CCNC)CCc1nn([In])cc1-2</smiles><smiles>CCOCc1c(C(=O)OCC)n(C)c2c1ccc1[nH]ncc12</smiles>

1- $\mathrm{CH}_{3} \mathrm{l}, \mathrm{Cs}_{2} \mathrm{CO}_{3}$

THF, $60^{\circ} \mathrm{C}$, quant.<smiles>CCOC(=O)c1c[nH]c2c1CCC(N)=C2C=N</smiles>

39

40

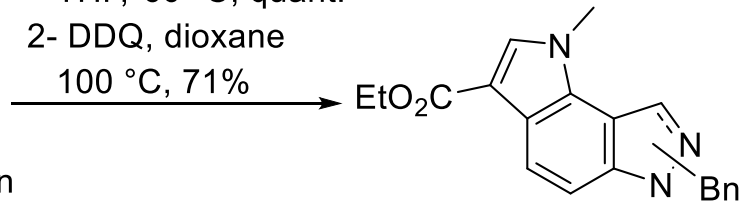

41

1- $\mathrm{CH}_{3} \mathrm{I}, \mathrm{NaH}$

DMF, $76 \%$<smiles>COC(=O)C=CO/C=C1\CCCc2nn([I-])cc21</smiles>

42
2- $\mathrm{HCl}, \mathrm{MeOH}, 80 \% \quad \mathrm{MeO}_{2} \mathrm{C}$

3- DDQ, dioxane reflux, $67 \%$<smiles>Cc1cc2ccc3[nH]ncc3c2n1C</smiles>

44<smiles>[R]c1c([R])n(C)c2c1ccc1[nH]ncc12</smiles>

45, $\mathrm{R}^{1}=\mathrm{H}, \mathrm{R}^{2}=\mathrm{CO}_{2} \mathrm{H}$

46, $\mathrm{R}^{2}=\mathrm{Cl}, \mathrm{R}^{2}=\mathrm{CONH}_{2}$<smiles>[R]c1c(C(N)=O)c2ccc3n[nH]cc3c2n1C</smiles>

47, $\mathrm{R}=\mathrm{H}$

48, $\mathrm{R}=\mathrm{Ph}$

Scheme 6. Synthesis of dihydropyrrolo[2,3-e]indazoles from 4-oxo-4,5,6,7-tetrahydroindazole derivatives. ${ }^{24}$

compound 35, a cyclocondensation using low-valent rhodium and tert-butyl isocyanoacetate ${ }^{25}$ was performed before alkylation of the pyrrole nitrogen, aromatization and indazole deprotection. In another process, ketonitrile 39 (mixture of $\mathrm{N}$-benzylated regioisomers) was cyclized under acidic conditions to give 
tetrahydropyrroloindazole 40. Finally, a third process described the rearrangement and cyclization of Ovinyloxime 42 to produce 43. Nevertheless, these selected examples afforded tetrahydropyrrolo[2,3e]indazoles in low to modest yields. However, some interesting biological activities were found towards protein kinase $\mathrm{Cdc7} / \mathrm{Dbf} 4$ with $\mathrm{IC}_{50}$ values lower than $100 \mathrm{nM}$ for compounds 45-48.

Finally, a recent patent application showed that the pyrazoloindazolone scaffold can be obtained via Bartoli indole synthesis from 4-nitroindazolone $\mathbf{4 9}$. Compound $\mathbf{5 0}$ is expected to be developed as a drug to treat atherosclerosis. ${ }^{26}$
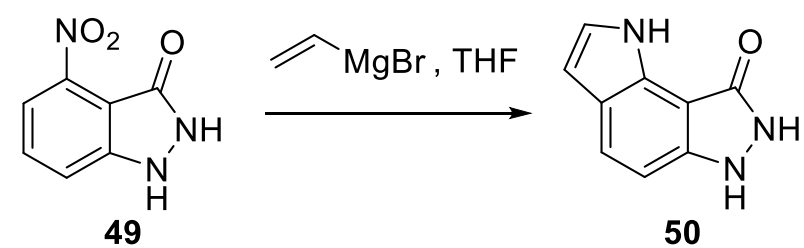

Scheme 7. Synthesis of pyrrolo[2,3-e]indazole-3-one $50 .^{26}$

\subsection{Pyrrolo[3,2-e]indazoles}

The regioisomeric 1,6-dihydropyrrolo[3,2-e]indazole synthesis has been reported by S. M. Bronner starting from the indolynes generated from indole derivatives $\mathbf{5 1}$ and $\mathbf{5 2}$ (Scheme 8). ${ }^{27}$ These reactive intermediates were trapped with ethyl diazoacetate to give the [3,2-e]- and the [2,3-g]-regioisomers in varying proportion depending on the substitution at the 6-position of the starting indole derivative. The 1,6-dihydropyrrolo[3,2$e$ ]indazole was favored in the case of a bromine substitution, and this preference was reversed in the case of $\mathrm{R}$ $=\mathrm{H}$.
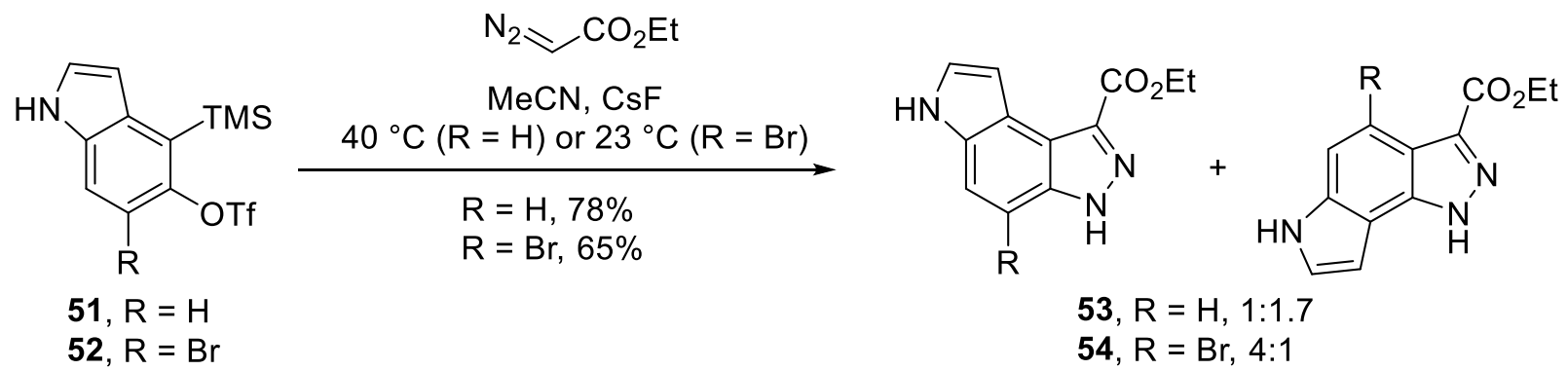

53, $\mathrm{R}=\mathrm{H}, 1: 1.7$

54, $\mathrm{R}=\mathrm{Br}, 4: 1$

Scheme 8. Indolyne trapping with ethyldiazoacetate leading to 53 or $54 .^{27}$

Another strategy was reported in 2014 by M. Chakrabarty and collaborators, ${ }^{28}$ starting from 5aminoindazole 55, which was iodinated/acylated to give 57. Using a Sonogashira/Cacchi procedure from $\mathbf{5 7}$ involving consecutive palladium-catalyzed Sonogashira coupling, aminopalladation and reductive elimination, the 1,6-dihydropyrrolo[3,2-e]indazoles $\mathbf{5 8}$ were obtained in good yields (Scheme 9). Contrarily to the preceding example, the regioselectivity of the reaction was controlled by the appropriate functionalization at the 4- and 5-positions of compound 57. This strategy appeared recently in a PCT patent application of Radius Pharmaceuticals, focused on the preparation of substituted indoles as estrogen receptor-modulating compounds. ${ }^{29}$ Compounds $\mathbf{5 9}$ were reported (Scheme 9), showing high activity towards the MCF7 cell line, with $\mathrm{IC}_{50}$ values lower than $1 \mathrm{nM}$ in proliferation inhibition assays in the presence of estradiol at a concentration of $10 \mathrm{pM}$. 
<smiles>Nc1ccc2c(cnn2S(=O)(=O)Oc2ccccc2)c1</smiles>
55

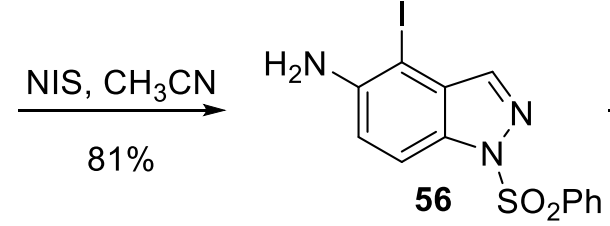

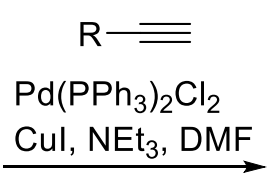

$82-94 \%$<smiles>[R]c1cc2c(ccc3[nH]ncc32)[nH]1</smiles>

$58 \mathrm{SO}_{2} \mathrm{Ph}$

$\mathrm{R}=\mathrm{H}$ (TMS in acetylene precursor), $-\left(\mathrm{CH}_{2}\right)_{3}-\mathrm{CH}_{3},-\left(\mathrm{CH}_{2}\right)_{4}-\mathrm{CH}_{3},-\left(\mathrm{CH}_{2}\right)_{5}-$ $\mathrm{CH}_{3},-\left(\mathrm{CH}_{2}\right)_{3}-\mathrm{CN}, \mathrm{Ph}, 4-\mathrm{Me}-\mathrm{C}_{6} \mathrm{H}_{4}$, 4$\mathrm{MeO}-\mathrm{C}_{6} \mathrm{H}_{4}$
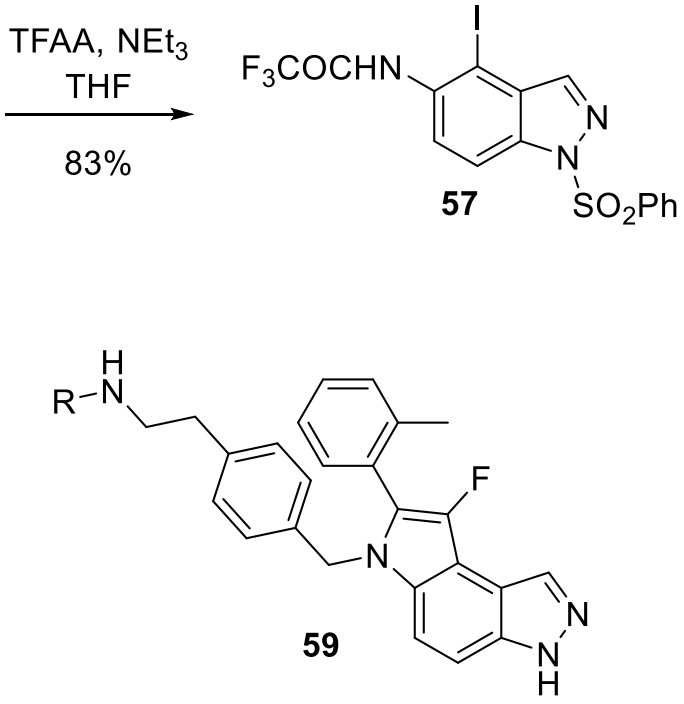

$\mathrm{R}=\mathrm{Et}, \mathrm{Pr}$, 2-F-ethyl, 3-F-propyl, cyclopropylmethyl, cyclobutylmethyl, cyclopropyl, cyclobutyl

Scheme 9. Preparation of 1,6-dihydropyrrolo[3,2-e]indazoles 58 via a Sonogashira/Cacchi procedure. $^{29}$ Structure of compounds 59.

Fischer indolization is another reaction that could be used for the preparation of 1,6-dihydropyrrolo[3,2e]indazole. Starting from 5-aminoindazole 60, I. Borza et al. reported the preparation of 61, as well as of its [2,3-g]-isomer from 6-aminoindazole. ${ }^{30}$ An hydrazone was first produced from 60 using the Japp-Klingemann procedure, and indolization in PPA led to compound 61 (Scheme 10). Compound 62 inhibited N-methyl-Daspartate (NMDA)-evoked elevation of cytoplasmic calcium concentration in primary rat neocortical cell cultures $\left(I C_{50}=20 \mathrm{nM}\right)$ and was active in an NR2B-selective binding assay $\left(\mathrm{IC}_{50}=5 \mathrm{nM}\right)$.
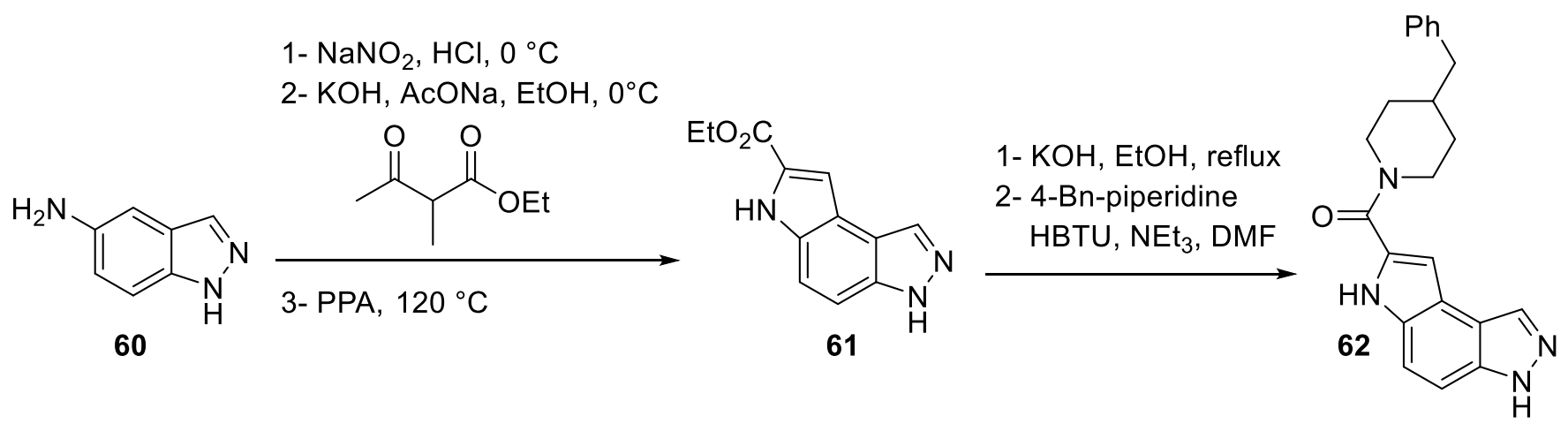

Scheme 10. Japp-Klingemann /Fischer strategy for the preparation of 1,6-dihydropyrrolo[3,2-e]indazole $61 .^{30}$

Isatine derivatives fused to a pyrazole system have also been reported (Scheme 11). ${ }^{31,32}$ The pyrrole ring was formed from 5-aminoindazoles 60 or 63 using chloral hydrate and hydroxylamine to give oxime 64 that can be cyclized under acidic treatment to give 65. Compounds 66 and 67 are CDK1 and CDK2 inhibitors. In particular, 67 inhibited CDK2/cyclinA with an $\mathrm{IC}_{50}$ of $2.2 \mathrm{nM}^{32}$ 


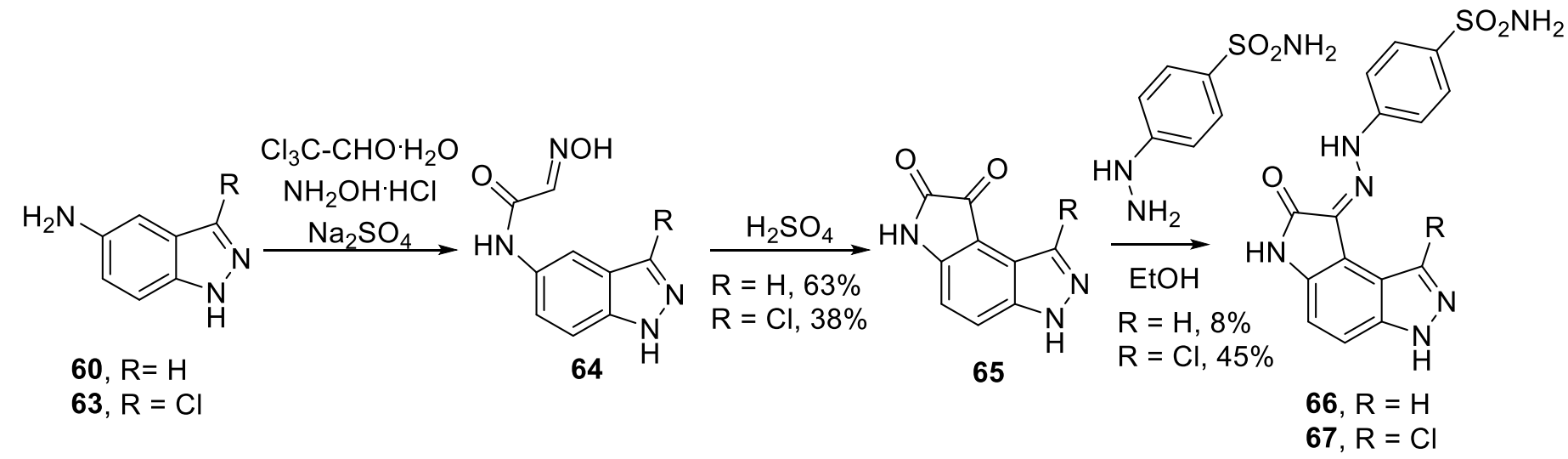

Scheme 11. Preparation of isatine derivatives $65-67 .^{31,32}$

\subsection{Pyrrolo[3,2-f]indazoles}

The preparation of pyrrolo[3,2-f]indazoles has been recently reported in a patent application by Jiangsu Hansoh Pharmaceutical group and the Shanghai Hansoh Biomedical company, relative to the preparation of pyrazolyl-containing tricyclic derivatives and their application as anticancer agents. ${ }^{33} \mathrm{~A}$ selected example is presented in Scheme 12. The pyrroloindazole scaffold was constructed by Cadogan-Sundberg cyclization of compound 70, promoted by triethyl phosphite, with a yield of $40 \%$. Compound 72 showed high protein kinase inhibitory potency of ERK-1 and ERK-2 ( $I \mathrm{C}_{50}=0.29$ and $0.17 \mathrm{nM}$, respectively), antiproliferative activity towards human pancreatic MiaPaCa-2 cells $\left(\mathrm{IC}_{50}=122.9 \mathrm{nM}\right)$, and it inhibited the growth of MiaPaCa-2 xenografts in nude mice.<smiles>[3H]n1nc(-c2ccncc2)c2cc(C=CC(=O)OC)c([N+](=O)[O-])cc21</smiles><smiles>[Y7]N1N=C(c2ccncc2)c2cc3cc(C(=O)N[C@@H](C)c4ccccc4)[nH]c3cc2N1[I+]</smiles>

Scheme 12. Synthesis of pyrrolo[3,2-f]indazole 71 via a Cadogan-Sundberg indole synthesis. ${ }^{33}$

The synthesis of quinonic derivatives of the pyrrolo[3,2-f]indazole scaffold has also been reported by $E$. Delfourne and collaborators, in a work dedicated to the synthesis of pyrazolic analogues of the marine alkaloids Wakayin and Tsitsikammamines. ${ }^{34,35}$ Selected examples are presented Scheme 13. The [3+2] 
cycloaddition of quinone $\mathbf{7 3}$ with diazomethane or diazomethane derivatives led to the pyrrolo[3,2-f]indazole 74 in mixture with its pyrrolo[2,3-f]indazole regioisomer 75.

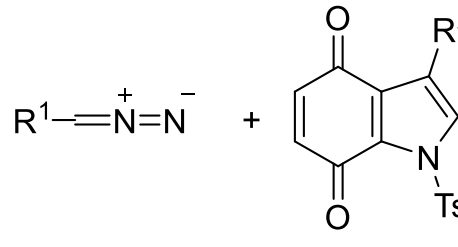

73<smiles>[R]C1=NNC2C(=O)c3c([R])cn([3H])c3C(=O)C12</smiles>

74<smiles>[R]c1cn([AsH-])c2c1C(=O)c1[nH]nc([R])c1C2=O</smiles>

75

$\mathrm{R}^{1}=\mathrm{H}, \mathrm{R}^{2}=-\left(\mathrm{CH}_{2}\right)_{2}-\mathrm{NHBoc}, 98 \%$

$\mathrm{R}^{1}=\mathrm{Ph}, \mathrm{R}^{2}=-\left(\mathrm{CH}_{2}\right)_{2}-\mathrm{NHBoc}, 49 \%$

$\mathrm{R}^{1}=-\left(\mathrm{CH}_{2}\right)_{2}-\mathrm{NHMOZ}, \mathrm{R}^{2}=\mathrm{H}, 70 \%$

Scheme 13. Cycloaddition of quinone 73 with diazomethane or diazomethane derivatives. ${ }^{34,35}$

\subsection{Pyrrolo[2,3-g]indazoles}

The first references of pyrrolo[2,4-g]indazole preparation dates from the 1960's in patent applications by American Cyanamide ${ }^{36,37}$, reporting compounds with analgesic and anti-inflammatory activity. ${ }^{36}$ Reaction of 76 with hydrazines and subsequent aromatization using $\mathrm{Pd} / \mathrm{C}$ in refluxing cumene led to a series of differently substituted compounds $\mathbf{7 8}$ (Scheme 14). This strategy has also been used for the synthesis of compounds $\mathbf{8 0}$ in a work dedicated to the preparation of potential inhibitors of soluble guanylate cyclase. ${ }^{38}$ In this work, DDQ was used instead of $\mathrm{Pd} / \mathrm{C}$ for the dehydrogenation, and the protecting group of the pyrrole moiety was changed to ethoxymethyl or the SEM group. The same approach was used for the preparation of pyrroloindazoles in the $[3,4-g]$ (see below) or $[3,2-g]^{39}$ series.

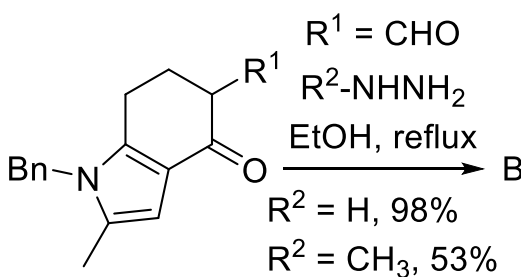

76

$$
\mathrm{R}^{1}=\mathrm{CHO}, \mathrm{CN}
$$

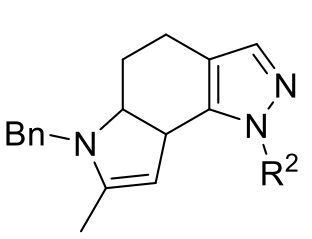

77

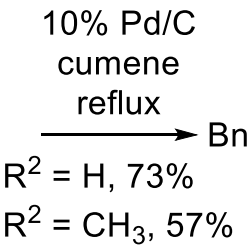

$\mathrm{R}^{2}=\mathrm{CH}_{3}, 57 \%$

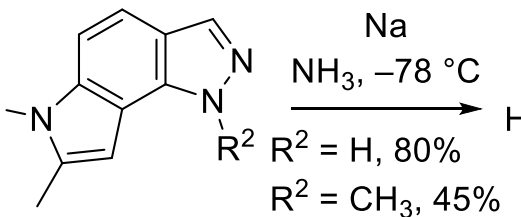

78<smiles>[R]n1ncc2ccc3[nH]c(C)cc3c21</smiles>

79

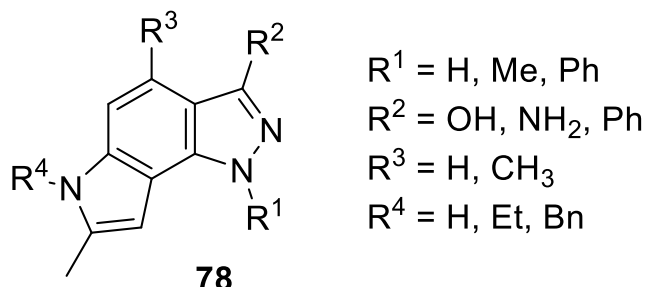<smiles>[R]n1ccc2c1ccc1cnn([R])c12</smiles>

$\mathrm{R}^{1}=\mathrm{Me}, \mathrm{Ph}$

$\mathrm{R}^{2}=\mathrm{CH}_{2} \mathrm{OEt}$, SEM

78

Scheme 14. General structure of compounds $\mathbf{7 8} 8^{36,37}$ or $\mathbf{8 0}^{38}$. Preparation of compounds $\mathbf{7 9}$ from $\mathbf{7 6 .} .^{36}$

As presented above for the preparation of pyrrolo[2,3-e]indazoles (Scheme 10), the work by Borza et al. was also carried out from 6-aminoindazole to get the [2,3-g]-regioisomers. ${ }^{30}$ Previously, Fischer indolization was also reported in the [2,3-g]-series, from 6-hydrazinoindazoles $\mathbf{8 1}$ (Scheme 15). ${ }^{40}$ Formation of the pyrrole 
nucleus could also be achieved by reaction of 6 -aminoindazoles 83 with arylglyoxal hydrates and cyclic 1,3dicarbonyl compounds to give $\mathbf{8 6 ^ { 4 1 }}$, or by condensation of 83 or 87 with benzoin, to give 7,8-diphenyl derivatives $\mathbf{8 5}$ and $\mathbf{8 6 ^ { 4 2 }}$, (Scheme 15). The pyrrolo[3,2-f]indazole scaffold could also be formed using this reaction, starting from 6 -amino-7-chloroindazole. ${ }^{42}$

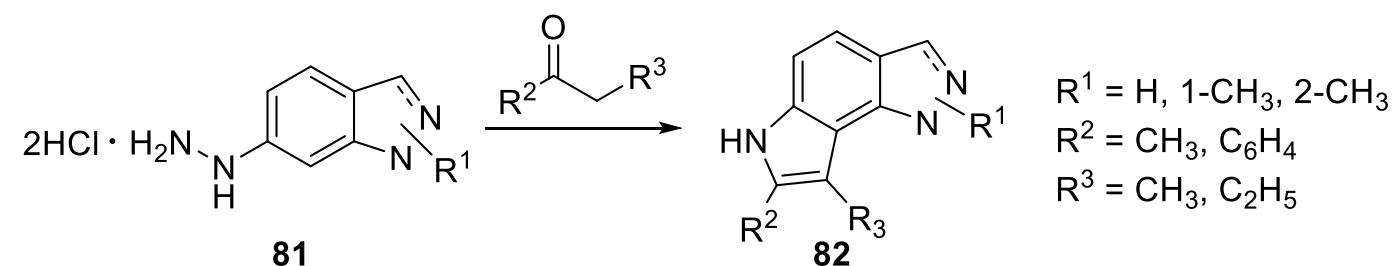<smiles>[R]C1([R])CC(=O)CC([R])([R15])C1</smiles><smiles>[R]Nc1cc(N)ccc1C=Nc1ccc2[nH]c(-c3ccccc3)c(-c3ccccc3)c2c1N=CC(=O)O</smiles>

Scheme 15. Fischer indolization from 6-hydrazinoindazole $\mathbf{8 1} .^{40}$ Three-component reaction using 6aminoindazole $\mathbf{8 3}$, arylglyoxal hydrates and cyclic 1,3-dicarbonyl compounds. ${ }^{41}$ Condensation of indazoles 83 and 87 with benzoin. ${ }^{42}$

In 2011, we reported the preparation of diversely substituted pyrrolo[2,3-g]indazoles. ${ }^{43,44}$ The method involved a palladium-catalyzed annulation from 6-amino-7-iodoindazole $\mathbf{9 0}$ and terminal or internal alkynes using $\mathrm{Pd}\left(\mathrm{PPh}_{3}\right)_{4}$ as a palladium source and XPhos as a ligand (Scheme 16). High yields were attained, and a single regioisomer could be obtained as in the cases of examples presented Scheme 16 . This synthetic method was used to prepare a series of potential Pim kinase inhibitors of general structure 92. In particular, high inhibitory potency was observed towards Pim-1 and Pim-3 protein kinases, with $I_{50}$ values in the submicromolar range $\left(92, \mathrm{R}_{1}=\mathrm{R}_{2}=\mathrm{H}, \mathrm{R}^{3}=\mathrm{NH}_{2}, \mathrm{IC}_{50}\right.$ Pim-3 $\left.=33 \mathrm{nM}\right)$. 


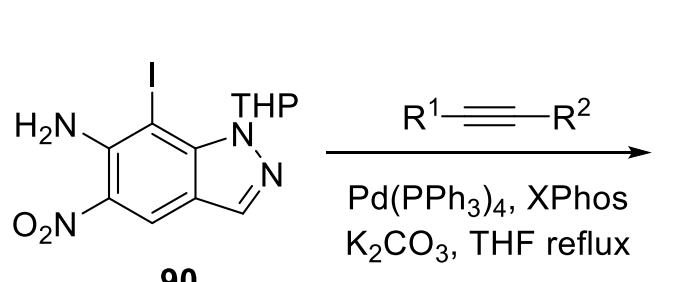

90<smiles>[R]c1[nH]c2c([N+](=O)[O-])cc3cnn([I-][3H])c3c2c1[R]</smiles>

$\mathrm{R}^{1}=\mathrm{TMS}, \mathrm{R}^{2}=\mathrm{H}, 91 \%$

$\mathrm{R}^{1}=\mathrm{H}, \mathrm{R}^{2}=\mathrm{Ph}, 97 \%$

$\mathrm{R}^{1}=\mathrm{CO}_{2} \mathrm{Et}, \mathrm{R}^{2}=\mathrm{CH}_{3}, 94 \%$<smiles>[R]c1[nH]c2c([R])cc3cn[nH]c3c2c1[R]</smiles>

92

Scheme 16. Palladium-catalyzed synthesis of pyrrolo[2,3-g]indazole derivatives $91{ }^{43}$ General structure 92 of potential Pim kinase inhibitors. ${ }^{44}$

Similarly to the $[3,2-e]$-series (see Scheme 11), fused pyrazole derivatives of isatin have been prepared from 6-aminoindazole ${ }^{45}$ or 6-amino-5-methylindazole. ${ }^{46}$ The synthetic method is similar, with the use of chloral hydrate and hydroxylamine hydrochloride to give a 2-(hydroxyimino)acetamide intermediate which was cyclized under acidic conditions.

\subsection{Pyrrolo[3,4-g]indazoles}

A single article on the preparation of 1,7-dihydropyrrolo[3,4-g]indazoles has been published by P. Barraja and collaborators. ${ }^{47}$ The strategy is the same as reported above for the preparation of pyrrolo[2,3-g]indazoles (see Scheme 14), involving isoindoles 93 to afford pyrazole derivatives 94 (Scheme 17). Reaction with alkyl- or arylhydrazine was rather regioselective (N1 for aryl, N2 for alkyl). Derivatives benzylated at the N1 instead of the $\mathrm{N} 2$ position could be obtained in an additional step of $\mathrm{N}$-alkylation from the non-substituted pyrazole (94, $\left.\mathrm{R}^{4}=\mathrm{H}\right)$. Oxidation using DDQ in benzene led to the 1,7-dihydropyrrolo[3,4-g]indazoles in 42-74\% yields.
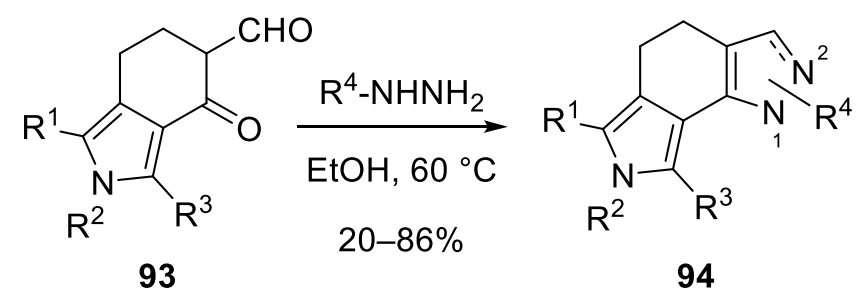

$$
\begin{aligned}
& \mathrm{R}^{1}=\mathrm{H}, \mathrm{CO}_{2} \mathrm{Et} \\
& \mathrm{R}^{2}=\mathrm{CH}_{3}, \mathrm{Bn} \\
& \mathrm{R}^{3}=\mathrm{H}, \mathrm{Me} \\
& \mathrm{R}^{4}=\mathrm{H}, 2-\mathrm{CH}_{3}, 2-\mathrm{Bn}, 1-\mathrm{C}_{6} \mathrm{H}_{4}, 1-\left(4-\mathrm{CH}_{3} \mathrm{O}-\mathrm{C}_{6} \mathrm{H}_{4}\right)
\end{aligned}
$$

94

Scheme 17. Synthesis of pyrazole derivatives $94 .^{47}$

Diels-Alder reaction has been frequently used in the synthesis of heterocyclic systems containing a phthalimide moiety. This strategy has also been applied to the preparation of pyrrolo[3,4-g]indazole-6,8diones 96, from styrylpyrazoles 95 and $N$-methylmaleimide (Scheme 18). ${ }^{48}$ 


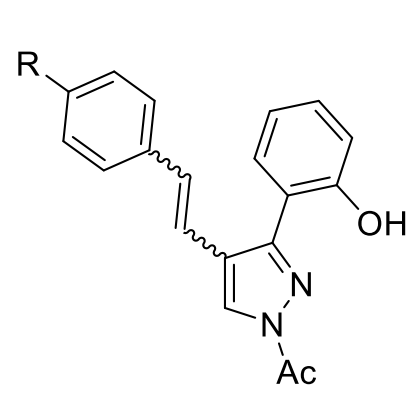

95

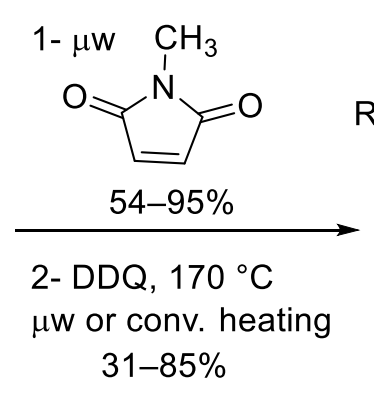

$31-85 \%$

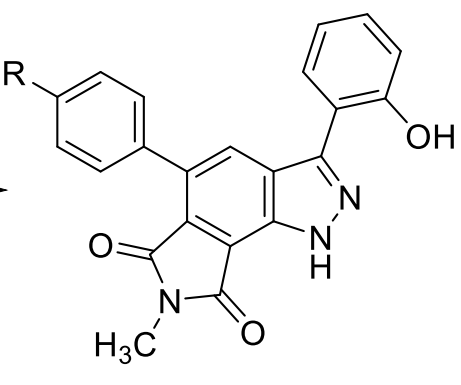

96
$\mathrm{R}=\mathrm{H}, \mathrm{Cl}, \mathrm{OEt}, \mathrm{NO}_{2}, \mathrm{CF}_{3}$

Scheme 18. Diels-Alder/dehydrogenation sequence leading to pyrrolo[3,4-g]indazole-6,8-diones $96 .{ }^{48}$

\subsection{Pyrrolo[3,2-g]indazoles}

This last example has been reported in a patent application deposited by the Memory Pharmaceuticals Corporation, in a work related to the preparation of ligands for the $\alpha 7$ nicotinic acetylcholine receptor. ${ }^{49}$ The synthesis started from the adequately functionalized indazole 97 (Scheme 19). A Negishi cross-coupling was first carried out to introduce the 2-carbon atom chain necessary for pyrrole formation. Reduction of the nitro group and acetal hydrolysis/cyclization led to compound $\mathbf{1 0 0}$ in $72 \%$ yield.

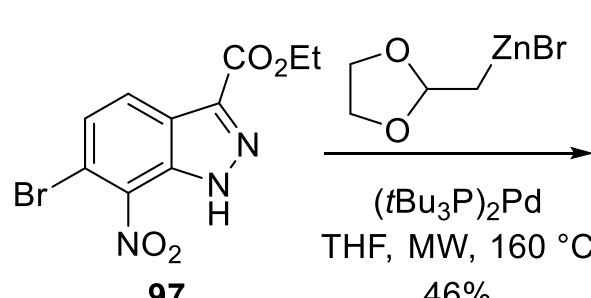

97<smiles>NC(=O)c1n[nH]c2c([N+](=O)[O-])c(CC3OCCO3)ccc12</smiles>

98

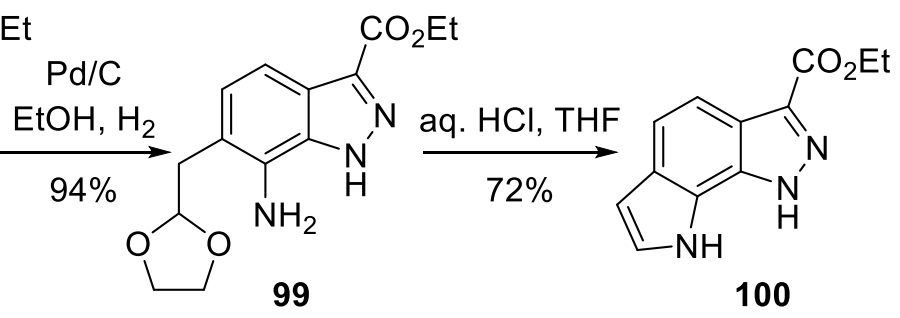

99

Scheme 19. Synthesis of 1,8-dihydropyrrolo[3,2-g]indazole $100 .^{49}$

\section{Conclusions}

Nitrogen-containing heteroaromatic derivatives are particularly interesting due to their various areas of application, especially in biology. The development of efficient methods allowing access to these scaffolds has sparked many efforts, and synthetic approaches using either multi-step synthesis, multi-component or metalcatalyzed reactions enabled the preparation of heterocyclic rings and the expansion of the chemical space in this domain. Nevertheless, the synthesis of many heterocyclic systems remains challenging in order to enlarge the scope of synthetic methodologies, control the regioselectivity or overcome reactivity and stability issues. This account, focused on pyrido[3,4-g]quinazolines, pyrazolo[3,4-g]quinoxalines and pyrroloindazoles, explored the existing synthetic methods to obtain these structures, some of them demonstrating potential biological activities, particularly protein kinase inhibitory potencies. The literature analysis showed that some series have not or sparsely been reported (e.g. pyrrolo[2,3-f]indazoles, pyrrolo[3,4-e]indazoles, pyrrolo[3,4$f$ jindazoles), or that the existing synthetic methods can limit the choice of substitution and functionalization, highlighting that the development of new methodologies for the preparation of simple but challenging heteroaromatic moieties is still needed. 


\section{References}

1. Thanikachalam, P. V.; Maurya, R. K.; Garg, V.; Monga, V. Eur. J. Med. Chem. 2019, 180, 562. https://doi.org/10.1016/j.ejmech.2019.07.019

2. Giraud, F.; Anizon, F.; Moreau, P. in Targets in heterocyclic systems; Attanasi, O. A.; Noto, R.; Spinelli, D. Eds.; Italian Society of Chemistry: Roma, 2014; 18, 1.

3. Moreau, P.; Anizon, F.; Giraud, F.; Esvan, Y. J. Recent Pat. Anti-Cancer Drug Discovery 2016, 11, 309. https://doi.org/10.2174/1574892811666160519141628

4. Giraud, F., Pereira, E.; Anizon, F.; Moreau, P. Eur. J. Org. Chem. 2019, 5025. https://doi.org/10.1002/ejoc.201900269

5. Ostroverkhova, O. Chem. Rev. 2016, 116, 13279. https://doi.org/10.1021/acs.chemrev.6b00127

6. Taylor, A. P.; Robinson, R. P.; Fobian, Y. M.; Blakemore, D. C.; Jones, L. H.; Fadeyi, O. Org. Biomol. Chem. 2016, 14, 6611.

\section{https://doi.org/10.1039/C6OB00936K}

7. Janosik, T.; Rannug, A.; Rannug, U.; Wahlström, N.; Slätt, J.; Bergman, J. Chem. Rev. 2018, 118, 9058. https://doi.org/10.1021/acs.chemrev.8b00186

8. Esvan, Y. J.; Zeinyeh, W.; Boibessot, T.; Nauton, L.; Théry, V.; Knapp, S.; Chaikuad, A.; Loaëc, N.; Meijer, L.; Anizon, F.; Giraud, F.; Moreau, P. Eur. J. Med. Chem. 2016, 118, 170.

https://doi.org/10.1016/j.ejmech.2016.04.004

9. Tazarki, H.; Zeinyeh, W.; Esvan, Y. J.; Knapp, E.; Chatterjee, D.; Schröder, M.; Joerger, A. C.; Khiari, J.; Josselin, B.; Baratte, B.; Bach, S.; Ruchaud, S.; Anizon, F.; Giraud, F.; Moreau, P. Eur. J. Med. Chem. 2019, $166,304$.

https://doi.org/10.1016/i.ejmech.2019.01.052

10. Zeinyeh, W.; Esvan, Y. J.; Josselin, B.; Baratte, B.; Bach, S.; Nauton, L.; Théry, V.; Ruchaud, S.; Anizon, F.; Giraud, F.; Moreau, P. Bioorg. Med. Chem. 2019, 27, 2083.

https://doi.org/10.1016/.j.bmc.2019.04.005

11. Zeinyeh, W.; Esvan, Y. J.; Nauton, L.; Loaëc, N.; Meijer, L.; Théry, V.; Anizon, F.; Giraud, F.; Moreau, P. Bioorg. Med. Chem. 2016, 26, 4327.

https://doi.org/10.1016/j.bmcl.2016.07.032

12. Hirabayashi, T.; Katsuno, M.; Smith, C. J.; Sherer, E.; Campeau, L.-C.; Balkovec, J.; Greenlee, W. J.; Li, D.; Guo, L.; Chan, T. Y.; Chen, Y.-H.; Chen, Y.; Chack-Alamannil, S.; Tan, J. Q. WO 2014099694, 2014; Chem. Abstr. 2014, 161, 156208.

13. Venugopalan, B.; Iyer, S. S.; Karnik, P. J.; de Souza, N. J. Heterocycles 1987, 26, 3173.

14. Venugopalan, B.; Bapat, C. P.; Karnik, P. J.; de Souza, N. J. Ind. J. Chem. B 1990, 29 B, 364.

15. Gavara, L.; Saugues, E.; Anizon, F.; Moreau, P. Tetrahedron 2011, 67, 1639. https://doi.org/10.1016/j.tet.2011.01.010

16. Gavara, L.; Saugues, E.; Alves, G.; Debiton, E.; Anizon, F.; Moreau, P. Eur. J. Med. Chem. 2010, 45, 5520. https://doi.org/10.1016/j.ejmech.2010.08.067

17. Zhao, Z.; Wisnoski, D. D.; Wolkenberg, S. E.; Leister, W. H.; Wang, Y.; Lindsley, C. W. Tetrahedron Lett. 2004, 45, 4873.

https://doi.org/10.1016/j.tetlet.2004.04.144

18. Lindsley, C. W.; Zhao, Z.; Leister, W. H.; Robinson, R. G.; Barnett, S. F.; Defeo-Jones, D.; Jones, R. E.; Hartman, G. D.; Huff, J. R.; Huber, H. E.; Duggan, M. E. Bioorg. Med. Chem. Lett. 2005, 15, 761. 
https://doi.org/10.1016/i.bmcl.2004.11.011

19. Barnett, S. F.; Defeo-Jones, D.; Haskell, K. M.; Huber, H. E.; Nahas, D. D.; Lindsley, C. W.; Zhao, Z.; Hartman, G. D. WO 2003084473, 2003; Chem. Abstr. 2003, 139, 323527.

20. Barnett, S. F.; Defeo-Jones, D.; Hartman, G. D.; Huber, H. E.; Stirdivant, S. M.; Heimbrook, D. C. US20040102360, 2004; Chem. Abstr. 2004, 141, 7131.

21. Lindsley, C. W.; Zhao, Z. WO 2003086404, 2003; Chem. Abstr. 2003, 139, 350755.

22. Myers, M. R.; Persons, P. E.; Ly, C. Q.; Spada, A. P. US19955476851, 1995; Chem. Abstr. 1995, 124, 232489.

23. Lyubchanskaya, V. M.; Alekseeva, L. M.; Savina, S. A.; Granik, V. G. Chem. Heterocycl. Comp. 2000, 36, 1276.

https://doi.org/10.1023/A:1017515300244

24. Vanotti, E.; Caldarelli, M.; Casuscelli, F.; Forte, B.; Menichincheri, M.; Scolaro, A.; Traquandi, G.; Vianello, P. WO 2008065054, 2008; Chem. Abstr. 2008, 149, 32298.

25. Takaya, H.; Kojima, S.; Murahashi, S.-I. Org. Lett. 2001, 3, 421.

https://doi.org/10.1021/ol0069296

26. Li, H. CN 109223775; Chem. Abstr. 2019, 170, 262540

27. Bronner, S. M.; Goetz, A. E.; Garg, N. K. J. Am. Chem. Soc. 2001, 133, 3832.

https://doi.org/10.1021/ja200437g

28. Barik, S. K.; Rakshit, M.; Kar, G. K.; Chakrabarty, M. Arkivoc 2014, 5, 1.

29. Miller, C. WO 2019144132; Chem. Abstr. 2019, 171, 238330.

30. Borza, I.; Bozo, E.; Barta-Szalai, G.; Kiss, C.; Tarkanyi, G.; Demeter, A.; Gati, T.; Hada, V.; Kolok, S.; Gere, A.; Fodor, L.; Nagy, J.; Galgoczy, K.; Magdo, I.; Agai, B.; Fetter, J.; Bertha, F.; Keserue, G. M.; Horvath, C.; Farkas, S.; Greiner, I.; Domany, G. J. Med. Chem. 2007, 50, 901.

https://doi.org/10.1021/jm060420k

31. Cuny, E.; Lichtenthaler, F. W.; Jahn, U. Chem. Ber. 1981, 114, 1624.

https://doi.org/10.1002/cber.19811140505

32. Bramson, H. N.; Corona, J.; Davis, S. T.; Dickerson, S. H.; Edelstein, M.; Frye, S. V.; Gampe, R. T.; Harris, P. A.; Hassell, A.; Holmes, W. D.; Hunter, R. N.; Lackey, K. E.; Lovejoy, B.; Luzzio, M. J.; Montana, V.; Rocque, W. J.; Rusnak, D.; Shewchuk, L.; Veal, J. M.; Walker, D. H.; Kuyper, L. F. J. Med. Chem. 2001, 44, 4339. https://doi.org/10.1021/jm010117d

33. Liu, S.; Zhou, Y.; Liu, Y.; Wu, X.; Liu, L.; Bao, R. WO 2019076336; Chem. Abstr. 2019, 170, 547754.

34. Legentil, L.; Benel, L.; Bertrand, V.; Lesur, B.; Delfourne E. J. Med. Chem. 2006, 49, 2979. https://doi.org/10.1021/jm051247f

35. Legentil, L.; Lesur, B.; Delfourne E. Bioorg. Med. Chem. Lett. 2006, 16, 427. https://doi.org/10.1016/i.bmcl.2005.09.063

36. McEvoy, F. J.; Smith, J. M.; Allen, D. S. US 3404157; Chem. Abstr. 1966, 65, 108063.

37. Remers, W. A.; Weiss, M. J. US 3321486; Chem. Abstr. 1968, 68, 21831.

38. Spyridonidou, K.; Fousteris, M.; Antonia, M.; Chatzianastasiou, A.; Papapetropoulos, A.; Nikolaropoulos, S. Bioorg. Med. Chem. Lett. 2009, 19, 4810.

https://doi.org/10.1016/j.bmcl.2009.06.047

39. Massa, S.; Stefancich, G.; Artico, M.; Corelli, F.; Silvestri, R. Farmaco, Ed. Sc. 1987, 42, 567.

40. Maksimov, N. Ya.; Chetverikov, V. P.; Kost, A. N. SU 685664; Chem. Abstr. 1980, 92, 41938.

41. Chen, D.-S.; Li, L.; Liu, J.-Y., Wei, M.; Chu, R.-H.; An, Q.; Zhang, M. J. Het. Chem. 2018, 55, 2951. 
42. Sequeria, S.; Seshadri, S. Indian J. Chem. Sect. B 1987, 26, 436.

43. Gavara, L.; Anizon, F.; Moreau, P. Tetrahedron 2011, 67, 7330.

https://doi.org/10.1016/j.tet.2011.07.029

44. Gavara, L.; Suchaud, V.; Nauton, L.; Thery, V.; Anizon, F.; Moreau, P. Bioorg. Med. Chem. Lett. 2013, 23, 2298.

https://doi.org/10.1016/j.bmcl.2013.02.074

45. Foster, R. H.; Leonard, N. J. J. Org. Chem. 1980, 45, 3072.

https://doi.org/10.1021/j001303a027

46. Jeanguenat, A.; Durieux, P.; Edmunds, A. J. F.; Hall, R. G.; Hughes, D.; Loiseleur, O.; Pabba, J.; Stoller, A.; Trah, S.; Wenger, J.; Dutton, A.; Crossthwaite, A. Biorg. Med. Chem. 2016, 24, 403.

https://doi.org/10.1016/j.bmc.2015.11.035

47. Spanò, Virginia; Montalbano, A.; Carbone, A.; Parrino, B.; Diana, P.; Cirrincione, G.; Barraja, P. Tetrahedron 2013, 69, 9839.

https://doi.org/10.1016/j.tet.2013.09.003

48. Silva, V. L. M.; Silva, A. M. S.; Pinto, D. C. G. A.; Elguero, J.; Cavaleiro, J. A. S. Eur. J. Org. Chem. 2009, 26, 4468.

https://doi.org/10.1002/ejoc.200900513

49. Xie, W.; Herbert, B.; Schumacher, R.; Nguyen, T. M.; Ma, J.; Gauss, C. M.; Tehim, A. WO 2005092890; Chem. Abstr. 2005, 143, 347334.

\section{Authors' Biographies}

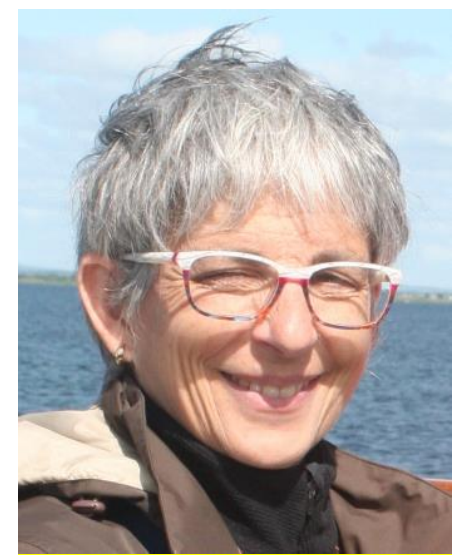

After a Master Degree in biophysicochemistry and cellular and molecular biology (1989), Pascale Moreau received her Ph.D (University of Orléans, France) in 1993 working on the synthesis and reactivity of 1,4benzodioxine derivatives. Then she joined Prof. Victor A. Snieckus' group at Waterloo University (Canada), as a postdoctoral fellow in 1994-1995, working on macrocycles synthesis and directed ortho-metalation. During a second post-doctoral position at Bristol-Myers-Squibb (Marne-la-Vallée, France) she focused on asymmetric synthesis. In 1996, she moved to Blaise Pascal University (Clermont-Ferrand, France) as a lecturer in the group of Prof. Michelle Prudhomme working on hemisynthesis of rebeccamycin derivatives. She was appointed as a Professor in 2007. She is currently the leader of "Enzyme and receptor inhibitors" group within the Institute of Chemistry of Clermont-Ferrand. Her current research is devoted to the development of new bioactive heteroaromatic compounds. 


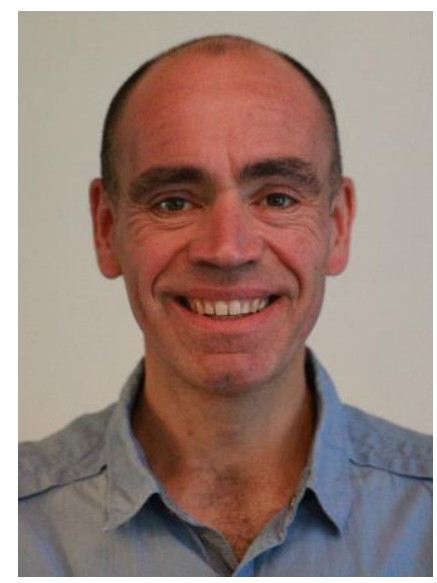

Fabrice Anizon obtained a Master in Chemistry in 1996 from Blaise Pascal University (Clermont-Ferrand, France), after carrying out research in the groups of Prof. G. Jeminet (Clermont-Fd) and Daniel T. Glatzhofer (Oklahoma University, United States). In 1999, he received his PhD in organic and biological chemistry at Blaise Pascal University, under the supervision of Prof. Michelle Prudhomme, working on the synthesis of rebeccamycin derivatives as topoisomerase I or protein kinase inhibitors. He joined the group of Prof. Philip J. Kocienski at the Universities of Glasgow (Scotland) and Leeds (England) as a post-doctoral fellow focusing on targeting peptides in drug delivery. He carried on in the same group as a Lecturer at the University of Leeds (2001), working in the fields of organometallic chemistry and asymmetric synthesis, and from September 2001 at Blaise Pascal University in the group of Prof. Michelle Prudhomme. He was appointed Professor in the same University in 2008. His research interests focus on the design and synthesis of biologically active heteroaromatic compounds. 